\title{
(5) 臨床面から見た画像圧縮の問題点
}

\section{Data Compression of Digital X-ray Images}

\section{慶応義塾大学医学部放射線科学教室＼cjkstart安藤 裕}

医用画像をデジタル化して画像データを保管・検索・転送を行う際に問題になるのは、大容量の記 憶装置と高速のデー夕通信網が必要となることである。近年になり、P A C S が病院で運用されるよ うになり、この問題点はますます重大となっている。胸部 X線画像をデジタル化すると例えば $2 \mathrm{kx} 2$ kx10bitで 5 M B のデータ量となる。現在広く使用されている記録メディアである光ディスクは、1 枚の容量が両面で 2．6 G Bであり、単純計算すると 5200 枚しか記録することができない。この ため、画像データの圧縮技術の開発および圧縮画像の評価が急務である。

データ圧縮の方法には、1) 可逆圧縮と2) 非可逆圧縮の 2 種類がある。可逆圧縮は、データ圧縮後、 データを伸張したときに完全に元に戻る圧縮方法であり、データの圧縮率は、約 $1 / 2 \sim 1 / 3$ あ る。一方非可逆圧縮は、データを完全には復元できないが、それと引換えに高い圧縮率を得ることが できる。一般には、データ圧縮というと後者の非可逆压縮を指すことが多い。非可逆压縮には、離散 的コサイン変換（D C T ）、離散的フーリエ変換、アダマール変換、ハール変換、スラント変換やベ クトル量子化法など様々の方法が用いられているが、医療分野では数值誤差や高速な变換が可能など の理由で、DＣＴが多く利用されている。データの压縮率は、復元された画像の画質に大きな影響を 与えるので、極端に高い压縮率を期待することは不可能である。多くの施設からの報告では、1／1 $0 \sim 1 / 20$ 位の值が標準的である。われわれの行った研究でも、1／100庄縮率ならばおおむね 問題がない結果であった。

これらの圧縮率は、元になるX線画像と復元画像をどのような目的で利用するかにより、最適值を 決定する必要がある。単に教材用に画像を保存する必要もあれば、読影目的で保管することああろう。 また、定期検診のように経時的に過去の画像を比較参照の目的で保存する場合むあろう。臨床的には、 原画像の種類と復元画像の利用目的により許容される压縮率が変化するので十分に注意して圧縮率を 選択する必要がある。

\section{(6) 画像デー夕通信規格の標準化と問題点 Standardization for Medical Image Communication Network}

\section{信州大学医学部放射線医学教室＼cjkstart滝沢正臣}

最近のティシタル画像振影機器の増加は、画像の電子的な保管や管理の将来型ともいえる P A C $S$ を出現させたが、当初の予测と異なり発想啳10年を経過した1992年においても総合的なシステム はパイロット運用の範囲にある。この原因として、多くの問題が考えられるが、これらは1990年に 行った画像の保管・管理に関しての全国調査においても、ユーザーにより数多く指摘されている。

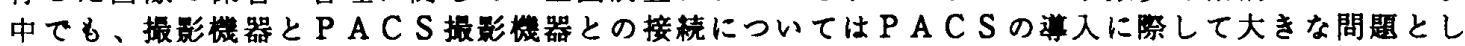
ている。このため、ここでは標準化に関して掫影機器と P A C S 機器間の通信用規格解説を中心と して、将来的に画像交换や㭘索を容易とするために必要な事柄をとりあげる。

データ通信を行うための規格の制定は国際レベル（I S O-International Standard Organizat ion）で行われているが、最近では多様なコンピュータとネットワークにより、画像をはじめ各種の マルチメティィア伝送に対応した解放型のシステム間相互通信の規格であるＯS I (Open Systen In terconnection）が将来の標準として広く世界で使われて行くと予測される。従って、医療用画像の 伝送規格もこれに準拠する必要がある。

1985年にA C R. (Anerican Col lege of Radiology) と、N E M A (National Electrical Manuf acturers Association) が共同で作成した医用画像通信のためのACRーN E M A 規格はこのOS I の考え方に準拠している。日本では、この規格の出される前から、画像記録形式などに関連する 標準化について検討が行われていた（尾上班）が、国際的な連携を重視しACR-NEMA規格に 準拠した規格化の検討した（MI P S 委貝会）。検討の䊅果、すべての画像を対象としたACR一 NEMA規格は、これを実行するハードゥエアゃソフトウエアの開発などに負担がかかることなど が考えられたため、基本的にはACR－N E M A 規格に染拠し、これを简易化したサブセット版、 M I P S 規格-87が作成された。ACR - N E M A 規格との違いは、漢字使用への配虑、コマン ドの制限、チャネル数の制限、画像種類の制限などであった。その後、A C R - N E M A 規格も、 より简略化された規格の使用を珰めたが、これは日本での検討が正しかったことを示している。規 格はその後の改良でVersion2.0、となり現在にいたっている。 